\title{
Peroxiredoxin I maintains luteal function by regulating unfolded protein response
}

Hyo-Jin Park', Dong Gil Lee ${ }^{2}$, Jung Bae Seong², Hyun-Shik Lee², Oh-Shin Kwon², Beom Sik Kang², Jeen-woo Park², Sang-Rae Lee ${ }^{3}$ and Dong-Seok Lee Le, $^{2 *}$

\begin{abstract}
Background: Mounting evidence shows that ROS regulation by various antioxidants is essential for the expression of enzymes involved in steroidogenesis and maintenance of progesterone production by the corpus luteum (CL). However, the underlying mechanisms of peroxiredoxin 1 (PRDX1), an antioxidant enzyme, in luteal function for progesterone production in mice have not been reported. The aim of this study was to evaluate the functional link between PRDX1 and progesterone production in the $\mathrm{CL}$ of $\operatorname{Pr} d x 1$ knockout (K/O) mice in the functional stage of $\mathrm{CL}$.

Methods: The expression pattern of the unfolded protein response (UPR) signaling pathways, endoplasmic reticulum (ER) stress-induced apoptosis related genes and peroxiredoxins 1 (PRDX1) were investigated by western blotting analysis in $C L$ tissue of 10 weeks mice during functional stage of $C L$. The protein levels of these genes after ER-stress inducer tunicamycin (Tm), ER-stress inhibitor tauroursodeoxycholic acid (TUDCA) and ROS scavenger, $\mathrm{N}$-acetylcysteine (NAC) stimulation by intraperitoneal (i.p) injection were also investigated in CL tissue of wild type (WT) mice. Finally, we examined progesterone production and UPR signaling related gene expression in $\mathrm{CL}$ tissue of Prdx1 K/O mice.
\end{abstract}

Results: We demonstrated that PRDX1 deficiency in the functional stage activates the UPR signaling pathways in response to ER stress-induced apoptosis. Interestingly, CL number, serum progesterone levels, and steroidogenic enzyme expression in Prdx1 K/O mice decreased significantly, compared to those in wild type mice. Levels of UPR signaling pathway markers (GRP78/BIP, P50ATF6, and phosphorylated (p)-elF2) and ER-stress associated apoptotic factors (CHOP, p-JNK, and cleaved caspase-3) were dramatically increased in the CL tissue of Prdx1 K/O mice. In addition, administration of the NAC, reduced progesterone production and activated ER-stress-induced UPR signaling in the $\mathrm{CL}$ tissue obtained from the ovary of $\operatorname{Prdx} 1 \mathrm{~K} / \mathrm{O}$ mice. Taken together, these results indicated that reduction in serum progesterone levels and activation of ER-stress-induced UPR signaling are restored by NAC injection in the CL of Prdx1 K/O mice.

Conclusion: These observations provide the first evidence regarding the basic mechanisms connecting PRDX1 and progesterone production in the functional stage of $\mathrm{CL}$.

Keywords: Corpus luteum, Peroxiredoxin 1, Unfolded protein response, Apoptosis

\footnotetext{
* Correspondence: lee1@knu.ac.kr

${ }^{2}$ School of Life Sciences, BK21 Plus KNU Creative BioResearch Group,

Kyungpook National University, Daegu, South Korea

${ }^{4}$ College of Natural Sciences, Kyungpook National University, Daegu 702-701,

Republic of Korea

Full list of author information is available at the end of the article
}

(c) The Author(s). 2018 Open Access This article is distributed under the terms of the Creative Commons Attribution 4.0 International License (http://creativecommons.org/licenses/by/4.0/), which permits unrestricted use, distribution, and reproduction in any medium, provided you give appropriate credit to the original author(s) and the source, provide a link to the Creative Commons license, and indicate if changes were made. The Creative Commons Public Domain Dedication waiver (http://creativecommons.org/publicdomain/zero/1.0/) applies to the data made available in this article, unless otherwise stated. 


\section{Background}

Regulation of antioxidant enzymes and reactive oxygen species (ROS) production has been proposed as a major mediator of granulosa/cumulus cell communication, oocyte maturation [1], and luteal phase development in mice [2]. Previous studies showed that abnormal expression of antioxidant enzymes is associated with ROS production in female reproductive system such as those affecting adverse pregnancy outcomes [3], resumption of meiosis, ovarian functions, and reducing fertility $[4,5]$. In particular, excess ROS production, especially in the corpus luteum (CL), induces hormone imbalance and luteal phase defect in female mice [5]. To protect cells against the damaging and toxic effects of ROS, antioxidant enzymes, including catalase (CAT), glutathione peroxidase (GPX), superoxide dismutase (SOD), and peroxiredoxins (PRDXs) are activated in mammalian cells $[6,7]$. The peroxiredoxin family consists of six proteins (PRDX1-6), which can reduce hydrogen peroxide $\left(\mathrm{H}_{2} \mathrm{O}_{2}\right)$, lipid hydroperoxides, and peroxynitrite. PRDX 1-6 are categorized as typical 2-Cys peroxiredoxins, which are distinct from the atypical 2-Cys (PRDX5) and 1-Cys peroxiredoxins (PRDX 6) [8]. Among these PRDXs, PRDX1 is localized in the cytosol, where it interacts with various signaling molecules $[9,10]$. In addition, a relationship between granulosa cell stimulation and PRDX1 expression has been previously detected in the rat ovary [10].

The CL is a transient ovarian endocrine gland, which secretes progesterone, a hormone essential for regulation of the luteal phase [11]. Steroidogenic enzymes such as steroidogenic acute regulatory (StAR) protein, p450 cholesterol side-chain cleavage enzyme (P450scc), and $3 \beta$-hydroxysteroid dehydrogenase $(3 \beta$-HSD) are required $[12,13]$ for progesterone production by the luteal cells of the CL. Loss of progesterone production, followed by loss of luteal cell function, leads to CL regression [11]. Recent studies showed that $\mathrm{H}_{2} \mathrm{O}_{2}$ production from the $\mathrm{CL}$ tissue is important for luteal function, such as for steroidogenic enzyme activation and regression of CL during the luteal phase [14]. Therefore, regulation of ROS production can play an important role in progesterone production and maintenance of luteal functions during the CL life span. However, the mechanisms via which PRDX1 acts as a ROS regulator and enables progesterone production in mice CL have not been reported.

ROS production is induced by endoplasmic reticulum (ER) stress and activation of unfolded protein response (UPR) [15]. The UPR alleviates ER stress, rescues ER homeostasis, and prevents cell death via the induction of ER chaperone expression, reduction of protein synthesis, and degradation of unfolded and/or misfolded proteins using three ER-localized transmembrane proteins, namely, inositol-requiring enzyme 1 (IRE1 or ERN1), protein kinase
RNA (PKR)-like ER kinase (PERK), and activating transcription factor-6 (ATF6) [16]. Therefore, all three UPR pathways contribute to the induction of cell apoptosis or ER stress-associated cell death, under conditions of excessive ER stress. In addition, it is well known that C/EBP homologous protein (CHOP), cJUN NH2-terminal kinase (JNK) and caspase-12 have been implicated in apoptotic signaling in response to ER stress [17]. Previously, we demonstrated that ER stress affects progesterone production during the functional stage of CL in mice and bovine CL tissue of estrous cycle $[18,19]$. Additionally, reports show that PRDX4 protects against ER-stress mediated cell death by removing $\mathrm{H}_{2} \mathrm{O}_{2}$ [20]. However, the roles of PRDX1 in regulation of ER stress and UPR signaling pathways during progesterone production in the functional stage of CL has not yet been investigated.

Therefore, the aims of present study were: i) to investigate whether PRDX1 acts as an antioxidant and ROS-regulator during progesterone production, ii) to confirm the association of PRDX1 with oxidative stress-derived ER stress response and UPR activation using an ER stress inducer and inhibitor during the functional stage of CL in mice, and iii) to evaluate the changes in progesterone production, UPR signaling, and ER stress-mediated apoptosis in the CL tissue of $\operatorname{Prdx1}$ knockout (K/O) mice compared to those in wild type (WT) mice. Finally, we investigated whether injection of the ROS scavenger, $\mathrm{N}$-acetylcysteine (NAC), in $\operatorname{Prdx} 1 \mathrm{~K} / \mathrm{O}$ mice effectively controls progesterone production by altering the levels of enzymes involved in steroidogenesis and regulating ER stress in mice CL.

\section{Methods}

\section{Chemicals}

Unless otherwise stated, all chemicals and reagents used in this study were purchased from Sigma Aldrich (St. Louis, MO, USA).

\section{Animals}

Female C57/B6J mice (8-10-week-old) of wild type were purchased from Hyochang Bio-Science (Daegu, Korea) and Prdx1-deficient (Prdx1-/-) female mice (8-10-weeks old) maintained in accordance with the institutional guidelines of the Institutional Animal Care and Use Committee of the Korea Research Institute of Bioscience and Biotechnology (KRIBB, Daejeon, South Korea). Animals were maintained under standard environmental conditions (temperature at $20-22{ }^{\circ} \mathrm{C}$, humidity at $50-$ $60 \%$, and 12-h-dark/light cycles) with free access to food and water.

\section{Determination of estrous cycle}

The short reproductive cycle length observed in rodents is called the estrous cycle. The normal estrous cycle in 
rodents follows a 4-5-day pattern, the characteristics of which vary with the day [21]. We classified mice on the basis of the predicted time of hormone induced-superovulation as described previously [18]. In all mice, superovulation was achieved by intraperitoneal (i.p) injection of $5 \mathrm{IU}$ pregnant mare's serum gonadotropin/mouse $(n$ =5-6 in each group, 8-week-old) (PMSG; Sigma Aldrich), followed $48 \mathrm{~h}$ later by injection of $5 \mathrm{IU}$ human chorionic gonadotropin/mouse (hCG; Sigma Aldrich). Ovulation occurred $12 \mathrm{~h}$ after the hCG injection, and therefore, $16 \mathrm{~h}$ post-hCG injection was considered as the beginning of $\mathrm{CL}$ formation. CL tissues were collected from the ovaries of treated mice 16, 24, 48, 72 and $96 \mathrm{~h}$ after hCG administration (Fig. 1a). The luteal phase was divided into two groups, namely, the functional stage (16, 24 and $48 \mathrm{~h}$ ) and the regressing stage $(72,96 \mathrm{~h}$ ) on the basis of serum progesterone concentration and changes in steroidogenic enzyme expression during progesterone production. Mice were killed, blood was collected, and the ovaries were removed at the indicated time intervals. CL tissues were collected from the ovaries under a dissecting microscope and immediately frozen at $-70{ }^{\circ} \mathrm{C}$ until further use. All experiments were performed in triplicate, and each experiment was independently analyzed.

\section{Administration of tm, TUDCA, and NAC in female mice} C57BL/6 female mice (8-week-old) were administered tunicamycin ( $\mathrm{Tm} ; 0.5 \mu \mathrm{g} / \mathrm{g}$ body weight; Calbiochem, CA, USA) as an ER stress inducer, and tauroursodeoxycholic acid (TUDCA;0.5 $\mu \mathrm{g} / \mathrm{g}$ body weight; Calbiochem) or NAC $(1.0 \mu \mathrm{g} / \mathrm{g}$, Sigma) as ER stress inhibitors by i.p. injection at the indicated times (16 h). Saline was injected intraperitoneally in the control animals. After

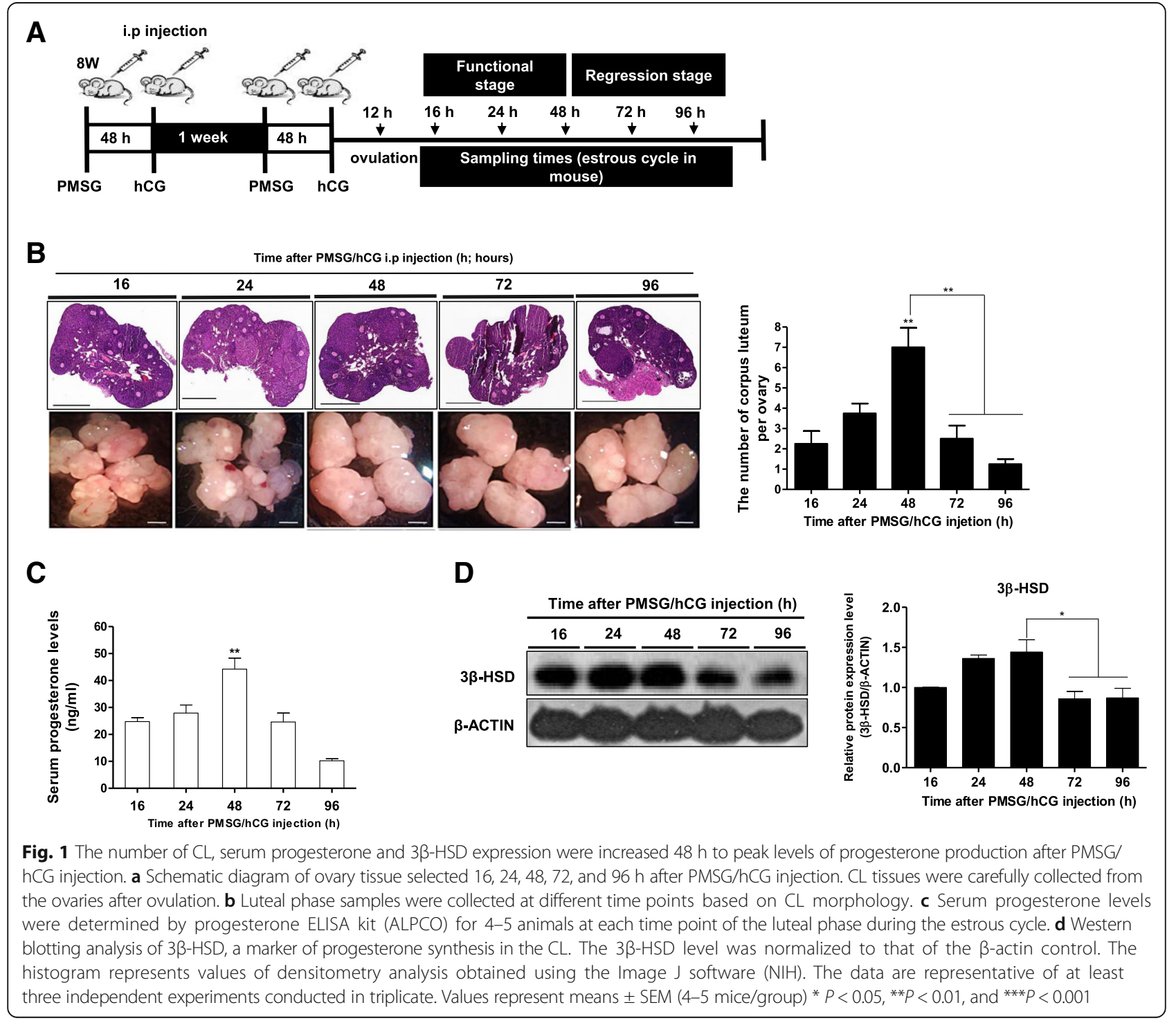


administration, the mice were sacrificed at the indicated times, and blood and CL tissues were collected.

\section{Progesterone estimation by enzyme immunoassay (EIA)}

For estimating serum progesterone concentration, blood was collected from female mice after each injection (16, 24, 48, 72 and $96 \mathrm{~h}$ after PMSG/hCG treatment). Serum was separated from blood and stored at $-20{ }^{\circ} \mathrm{C}$ until it was assayed for progesterone. Progesterone concentration was assessed using a progesterone EIA kit (ALPCO, Windham, NH, USA) according to the manufacturer's instructions.

\section{RNA extraction and reverse transcription polymerase chain reaction (RT-PCR)}

Total RNA was isolated from each individual CL tissue using the Trizol reagent (Invitrogen, Inc., CA, USA) according to the manufacturer's instructions. RNA concentration and purity were measured using a NanoDrop spectrophotometer (ASP-2680; ACTgene, NJ, USA). Next, $1 \mu \mathrm{g} / \mu \mathrm{l}$ total RNA and the AccuPower ${ }^{\circ}$ RT-PCR premix (Bioneer Inc., Daejeon, South Korea) were used to synthesize the cDNA. Primers specific for the mouse sequences of interest (Table 1) were designed using the National Center for Biotechnology Information (NCBI) database. PCR was performed using the following condition: $95{ }^{\circ} \mathrm{C}$ for 5 min, 30 cycles of $95{ }^{\circ} \mathrm{C}$ for $30 \mathrm{~s}, 55 \sim 60{ }^{\circ} \mathrm{C}$ for $30 \mathrm{~s}, 72{ }^{\circ} \mathrm{C}$ for $30 \mathrm{~s}$, and $72{ }^{\circ} \mathrm{C}$ for $5 \mathrm{~min}$. The PCR products were separated by electrophoresis on a $2 \%$ agarose gel with a known standard (100 bp ladder, Bioneer Inc.), stained with ethidium bromide, and photographed under UV illumination. Band intensities were quantified using the Image J software (National Institute of Health, Bethesda, MD, USA).

\section{Protein extraction and western blotting}

Lysates of CL tissue from each stage were prepared in PRO-PREP protein lysis buffer (iNtRON, Daejeon, Korea). The protein concentration for each sample was estimated using a Bradford dye-binding assay with bovine serum albumin (BSA) as a standard (Bradford, 1976). Aliquots of the proteins $(30 \mu \mathrm{g})$ were separated by sodium dodecyl sulfate-polyacrylamide gel electrophoresis (SDS-PAGE) on 12\% gels. After electrophoresis, the separated proteins were transferred onto nitrocellulose (NC) membranes (Pall Corporation, Port Washington, NY, USA). After blocking with $5 \%$ non-fat milk in Tris-buffered saline (TBS) with $0.1 \%$ Tween 20 at $4{ }^{\circ} \mathrm{C}$ under mild agitation, the membranes were incubated with 1:2000 diluted anti-CHOP, anti-p90ATF6, antiCREB-2, anti-3 $\beta$-HSD (Santa Cruz, Biotechnology, CA, USA), anti-GRP78/BIP, anti-p-eIF2 $\alpha$, anti-IRE1, antieIF2a, anti-JNK, anti-p-SAPK/JNK, anti-caspase-3, anti$\beta$-tubulin (Cell Signaling, Beverly, MA, USA), anti-p50ATF6 (IMG, San Diego, CA, USA), and anti-p-IRE1 $\alpha$ (Abcam, Cambridge, MA, USA) antibodies. The membranes were then incubated with secondary horse radish peroxidase (HRP)-conjugated anti-goat/mouse/rabbit IgG (Thermo, Rockford, IL). Antibody binding was detected using an enhanced chemiluminescence (ECL) kit (Advansta, CA, USA). Band intensities were quantified using the Image J software (NIH, MD, USA).

\section{Hematoxylin \& eosin staining}

The ovaries were isolated from the body and fixed with $4 \%$ formalin (Sigma Aldrich). The sections were stained with hematoxylin and eosin using a standard protocol described previously (Park, et al. 2013b, Park, et al. 2014) $[18,22]$. Thin sections were cut with a diamond knife and mounted. The sections were observed under an Olympus BX51 microscope (Olympus, Tokyo, Japan).

Table 1 Primer sequence for reverse transcription PCR

\begin{tabular}{|c|c|c|c|c|c|}
\hline Target & Accession numbers & Primer & Sequence reported 5'-3' & $\operatorname{Tm}^{\circ} \mathrm{C}$ & length (bp) \\
\hline \multirow[t]{2}{*}{$3 \beta-h s d$} & \multirow[t]{2}{*}{ NM_008293.3 } & Forward:5' & ACTGCAGGAGGTCAGAGCT & \multirow[t]{2}{*}{55} & \multirow[t]{2}{*}{401} \\
\hline & & Reverse:3' & GCCAGTAACACACAGAATACC & & \\
\hline \multirow[t]{2}{*}{$\operatorname{Prdx} 1$} & \multirow[t]{2}{*}{ NM_011034.4 } & Forward:5' & CACCCAAGAAACAAGGAGGA & \multirow[t]{2}{*}{53.5} & \multirow[t]{2}{*}{343} \\
\hline & & Reverse:3' & TGGTCCAGTGCTCACTTCTG & & \\
\hline \multirow[t]{2}{*}{ Star } & \multirow[t]{2}{*}{ NM_011485.4 } & Forward:5' & GAAAAGACACGGTCATCACT & \multirow[t]{2}{*}{56} & \multirow[t]{2}{*}{262} \\
\hline & & Reverse:3' & CCGTGTCTITTCCAATCCTC & & \\
\hline \multirow{2}{*}{$\begin{array}{l}\text { P450scc } \\
\text { (Cyp11a1) }\end{array}$} & \multirow[t]{2}{*}{ AF195119.1 } & Forward:5' & GCTGGAAGGTGTAGCTCAGG & \multirow[t]{2}{*}{57} & \multirow[t]{2}{*}{224} \\
\hline & & Reverse:3' & CACTGGTGTGGAACATCTGG & & \\
\hline \multirow[t]{2}{*}{ Gapdh } & \multirow[t]{2}{*}{ BC145810.1 } & Forward:5' & ACCACAGTCCATGCCATCAC & \multirow[t]{2}{*}{55} & \multirow[t]{2}{*}{452} \\
\hline & & Reverse:3’ & TCCACCACCCTGTTGCTGTA & & \\
\hline
\end{tabular}

$3 \beta$-hsd: 3ß-hydroxysteroid dehydrogenase, Prdx1: peroxiredoxin 1, Star: steroidogenesis acute regulatory, P450scc: cytochrome P450 side-chain cleavage, Tm: melting temperature 


\section{Immunohistochemistry}

The ovaries were fixed in formalin, embedded in paraffin, and cut into $3-\mu \mathrm{m}$-thick sections. The sections were deparaffinized and briefly heated. The sections were then treated with a protein blocking solution (Dako, CA, USA) and incubated with anti-phospho eIF2a (Cell Signaling). After washing with $0.1 \mathrm{M}$ TBS containing $0.01 \%$ Tween-20 (TBST), the sections were incubated with anti-rabbit polymer (Dako). Peroxidases bound to the antibody complex were visualized after treatment with a 3, 3'-diaminobenzidine (DAB) chromogen substrate solution (Dako). The DAB reaction was monitored under a microscope to determine the optimal incubation time and stopped with several washes of $0.1 \mathrm{M}$ TBS. The immunolabeled sections were dehydrated in a graded ethanol series, defatted in xylene, and mounted. The sections were examined under a bright field Olympus BX51 microscope and images were acquired using an Olympus DP 70 camera (Olympus, Japan).

\section{Statistical analysis}

All experiments were repeated at least three times, and percentage data obtained in this study are presented as the mean \pm standard error of the mean (SEM). These data were subjected to one-way analysis of variance (ANOVA), followed by Dunnett's multiple comparison test. Statistical analysis was performed using paired Student's t-test. Data obtained from WT and Prdx1 K/O mice CL tissues were compared using the unpaired Student's t-test. All calculations were performed using the GraphPad Prism 5.0 software package (GraphPad Software, San Diego, CA, USA). $P<0.05$ was considered to be statistically significant.

\section{Results}

\section{Measurement of progesterone production in $\mathrm{CL}$ tissue of} mouse

For delineating the timing of the luteal phase during the estrous cycle post-PMSG/hCG injection, we used a methods of hormone injection for synchronization of estrous cycle as previously described by Park et al., [18].

We observed the morphology and determined the number of collected CL tissues microscopically at 16, 24, 48, 72 and $96 \mathrm{~h}$ after PMSG/hCG injection (Fig. 1a and b). Next, we determined the serum progesterone level and the expression of $3 \beta-\mathrm{HSD}$, a classical steroidogenic enzyme involved in progesterone biosynthesis, using the progesterone ELISA kit (ALPCO) and western blot analysis during mice estrous cycle, respectively. Serum progesterone level was significantly increased $(P<0.01) 48 \mathrm{~h}$ after the PMSG/hCG injection (Fig. 1c). Protein levels of $3 \beta$-HSD showed the same pattern as that of serum progesterone till the $\mathrm{CL}$ functional stage, but rapidly decreased after $48 \mathrm{~h}$ (Fig. 1d). Based on these results, we concluded that the time point $(48 \mathrm{~h})$ corresponding to peak progesterone levels in CL tissues during the entire luteal phase after PMSG/hCG injection should be used for subsequent experiments.

\section{ER-stress-induced reduction in progesterone production at the functional stage of $\mathrm{CL}$ is recovered by the ROS scavenger NAC}

In our previous study, we demonstrated that ER stress affects progesterone production during the functional stage of CL. In addition, ER stress-mediated apoptosis induced CL regression in the mouse luteal phase [18]. Recent studies indicate that ROS production can be induced by ER stress [23]. Therefore, we investigated whether progesterone production is regulated by the ROS scavenger under ER stress in the functional stage of CL. To analyze the relationship between ROS and ER stress during progesterone production in the CL tissue at the peak of progesterone synthesis (48 $\mathrm{h}$ after PMSG/ hCG injection), we performed the experiment as shown in Fig. 2a. We used Tm as an ER stress inducer, TUDCA as an ER stress inhibitor, or NAC as a ROS scavenger. Mice injected with Tm $(0.5 \mu \mathrm{g} / \mathrm{g})$ showed dynamic deficiency of luteal function with low serum progesterone and reduction in $3 \beta-\mathrm{HSD}$ and $\mathrm{P} 450$ scc protein levels in the CL. Compared to the Tm-treated group, serum progesterone level recovered significantly $(P<0.05)$ in the group where NAC $(1.0 \mu \mathrm{g} / \mathrm{g})$ was added after $\mathrm{Tm}$ $(0.5 \mu \mathrm{g} / \mathrm{g})$ pre-treatment (Fig. 2b). Addition of NAC as a recovery effect like a TUDCA also significantly increased the protein levels of $3 \beta-\mathrm{HSD}$ and P450scc in CL (Fig. 2c). On the contrary, NAC or TUDCA administration in mice pre-treated with $\mathrm{Tm}$ decreased the expression level of CHOP as an ER stress-mediated apoptotic factors during the functional stage of $\mathrm{CL}$ $(P<0.001)$ (Fig. 2c). These results demonstrate that the regulation of ER stress-induced ROS production is required for maintaining progesterone production during the functional stage of CL in mice.

\section{Prdx1 knockout reduced $C L$ number, and levels of serum progesterone, 3 $\beta$-HSD, and P450ssc}

The above results underline the necessity of regulating ROS synthesis for maintaining progesterone production during the functional stage of CL (Fig. 2). We investigated whether PRDXs can act as antioxidants for maintaining progesterone production.

The expression of the PRDXs at 16, 24, 48, 72 and $96 \mathrm{~h}$ after PMSG/hCG injection were analyzed (Fig. 3a). Interestingly, PRDX1 was continuously expressed in CL during the entire luteal phase (Fig. 3b), irrespective of the changes in $3 \beta-H S D$ expression. In contrast, western blotting showed that the other PRDX proteins (2-6) were not expressed continuously during the entire luteal 


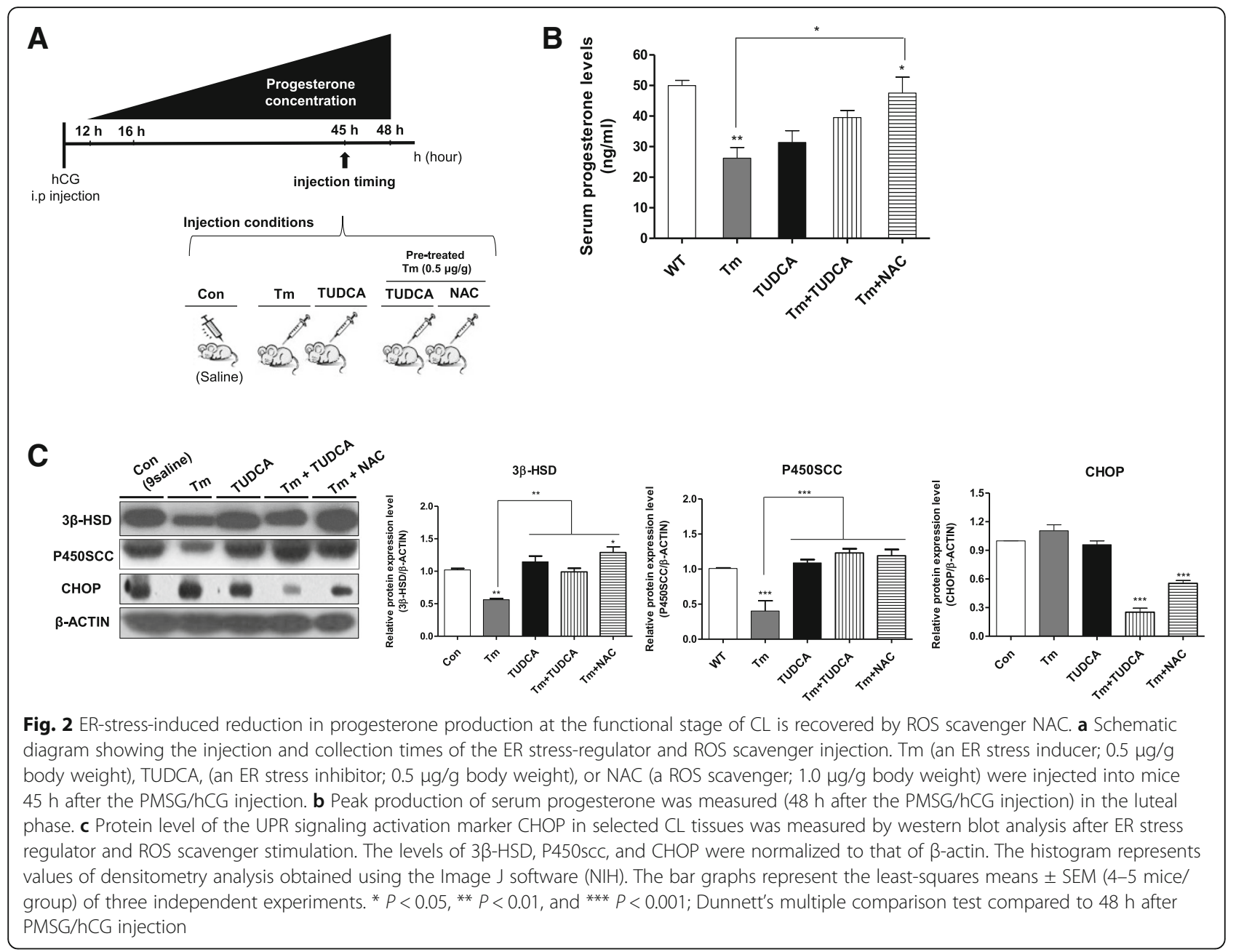

phase (Additional file 1: Figure S1). The PRDX1 level was increased by Tm treatment and recovered by TUDCA at the peak time point of progesterone production (Fig. 3c and d). TUDCA or NAC injection after Tm also decreased PRDX1 level compared to Tm only treatment (Fig. 3c and d). These results indicated that continuously expressed PRDX1 in CL during the entire luteal phase may be involved in ROS regulation for maintaining progesterone production in the functional stage of CL. Therefore, to investigate whether PRDX1 acts as an antioxidant and ROS-regulator during progesterone production in the functional luteal stage after PMSG/hCG injection, we evaluated the changes in progesterone production and expression of ER stress marker genes in the CL tissue of $\operatorname{Prdx} 1 \mathrm{~K} / \mathrm{O}$ mice and compared them with those of WT mice. First, to determine the CL number, the ovary from $\operatorname{Prdx} 1 \mathrm{~K} / \mathrm{O}$ and WT mice were subjected to genotyping and $\mathrm{H} \& \mathrm{E}$ staining, respectively (Fig. 4a). The number of formed CL and ovary size in $\operatorname{Prdx} 1 \mathrm{~K} / \mathrm{O}$ mice dramatically decreased $(P<0.01$; fold 2.8, Fig. 4b) $48 \mathrm{~h}$ after the PMSG/hCG injection. Similarly, the serum progesterone concentration and protein levels of $3 \beta$-HSD and P450ssc were significantly reduced compared to those in the CL of WT mice (Fig. 4c and d). Furthermore, to determine the effect of PRDX1 on progesterone production in $\mathrm{CL}$ tissue, we observed the ovary morphology in wild type, and $\operatorname{Prdx} 1$ heterozygous and homozygous K/O mice. Although the ovary size in Prdx1 heterozygous mouse was slightly reduced, the levels of serum progesterone and steroidogenic enzymes in the $\mathrm{CL}$ tissue of $\operatorname{Prdx} 1$ heterozygous mice showed the same pattern as that of WT mice $48 \mathrm{~h}$ after PMSG/hCG injection (Additional file 2: Figure S2). These results demonstrate that absence of PRDX1 in the functional luteal stage after PMSG/hCG injection decreased CL number and ovary size compared to those of WT mice, which reduces serum progesterone and protein levels of the steroidogenesis enzymes $3 \beta$-HSD and P450ssc.

\section{PRDX1 deficiency induced UPR signal activation and ER stress-mediated apoptosis in $\mathrm{CL}$ functional stage} We investigated whether PRDX1 deficiency is involved in UPR signaling (GRP78/BIP, p-EIF2 $\alpha$, p50ATF6, and 


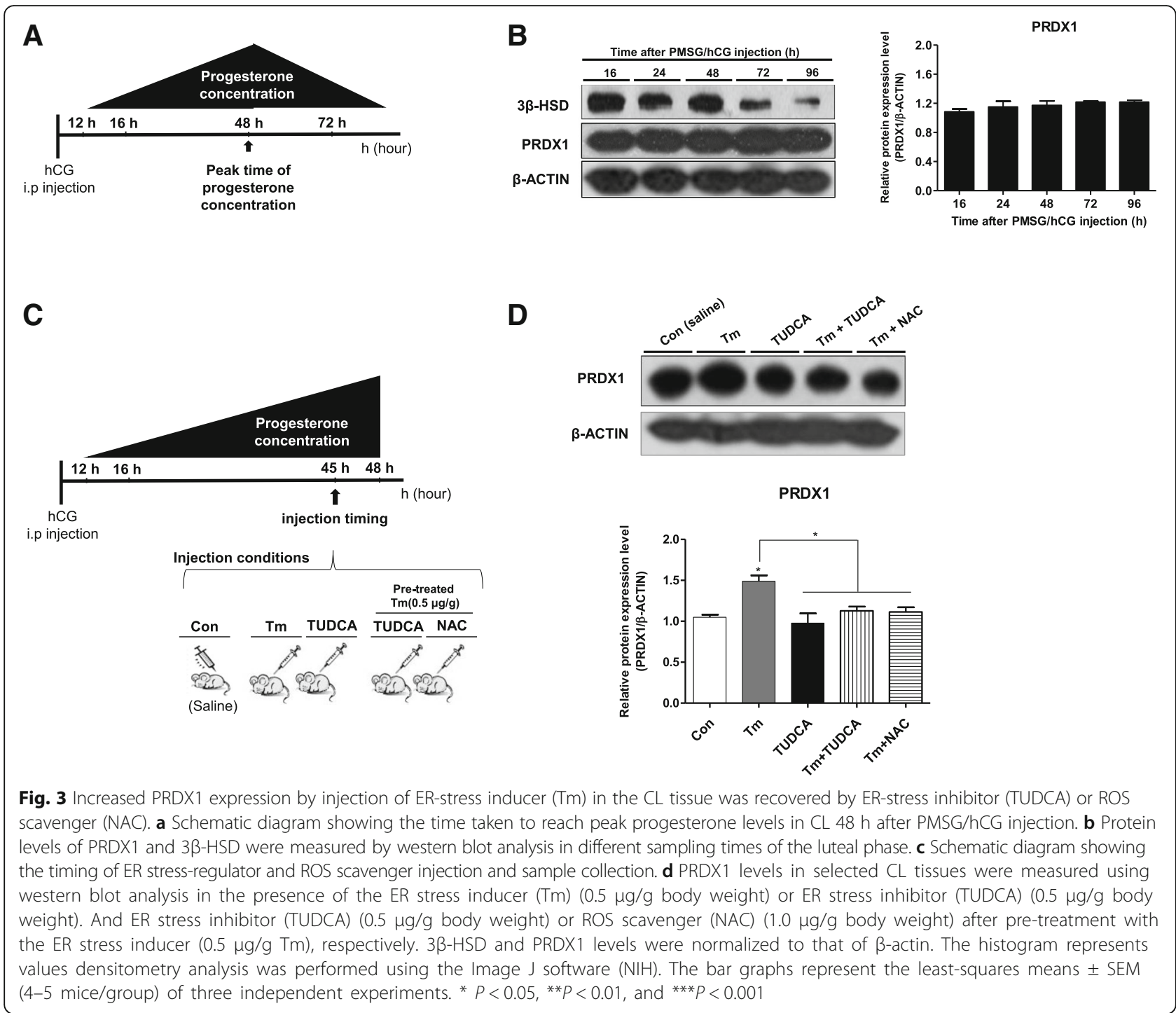

p-IRE1) or ER stress-mediated apoptosis (CHOP, p-JNK, and cleaved caspase-3) in the functional luteal stage using western blotting analysis and the CL tissue of WT and $\operatorname{Prdx} 1 \mathrm{~K} / \mathrm{O}$ mice. As shown in Fig. 5a, the levels of GRP78/BIP, p50ATF6, and p-EIF2 $\alpha$ were dramatically increased $(P<0.01)$ in the CL tissue of $\operatorname{Prdx} 1 \mathrm{~K} / \mathrm{O}$ mice, but, the levels of total EIF2 $\alpha$ and p-IRE1 showed no change compared to those of WT mice. The levels of CHOP, p-JNK, and cleaved caspase-3 were also significantly increased (CHOP; $P<0.05, \mathrm{p}-\mathrm{JNK}$, and cleaved caspase-3; $P<0.01$ ) in the $\mathrm{CL}$ of $\operatorname{Prdx1} \mathrm{K} / \mathrm{O}$ mice (Fig. 5b). In addition, immunohistochemistry (IHC) showed that the levels of p-EIF2 $\alpha$, ATF6, and cleaved caspase- 3 were higher in the ovary of $\operatorname{Prdx} 1 \mathrm{~K} / \mathrm{O}$ mice than in the ovary of WT mice (Fig. 5c). Therefore, these results demonstrated that PRDX1 deficiency during functional luteal stage activates the UPR signaling pathways in response to ER stress-mediated apoptosis.
Restoration of impaired progesterone production and UPR signaling activation in response to ER stress by NAC injection in Prdx1 knockout mice

As shown in Fig. 2, the NAC-mediated decrease in ER stress-induced ROS levels is required for maintaining progesterone production during the luteal functional stage. Thus, we investigated whether NAC injection in $\operatorname{Prdx} 1 \mathrm{~K} /$ $\mathrm{O}$ mice restores the reduced serum progesterone concentration and protein levels of steroidogenesis enzymes in the ovaries of $\operatorname{Prdx1} \mathrm{K} / \mathrm{O}$ mice. First, we injected NAC $45 \mathrm{~h}$ after the PMSG/hCG injection, and collected CL tissue from the ovary $3 \mathrm{~h}$ after the NAC injection. As shown in the Fig. 6a, serum progesterone production, which was rapidly reduced $(P<0.01$; compared to WT mice) in the CL tissue of $\operatorname{Prdx} 1 \mathrm{~K} / \mathrm{O}$ mice, recovered significantly $(P<0.05$; compared to $\operatorname{Pr} d x 1 \mathrm{~K} / \mathrm{O}$ mice) after the NAC injection. We also investigated whether NAC treatment of $\operatorname{Prdx} 1 \mathrm{~K} / \mathrm{O}$ mice recovered steroidogenic enzyme expression and 
A [Performing genotyping in PRDX1 -/- knockout (K/O) mice]

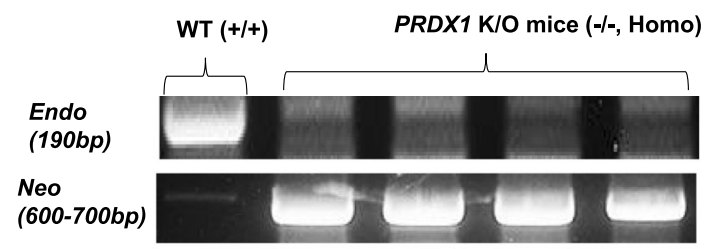

B

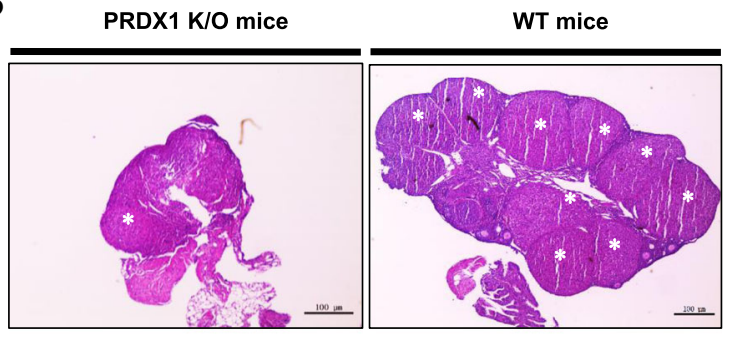

*; corpus luteum

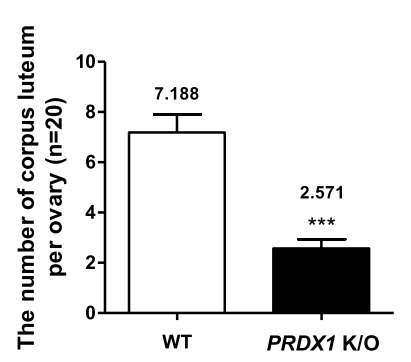

C

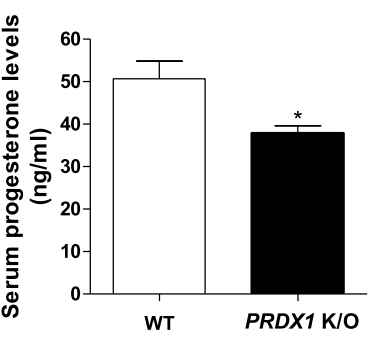

D
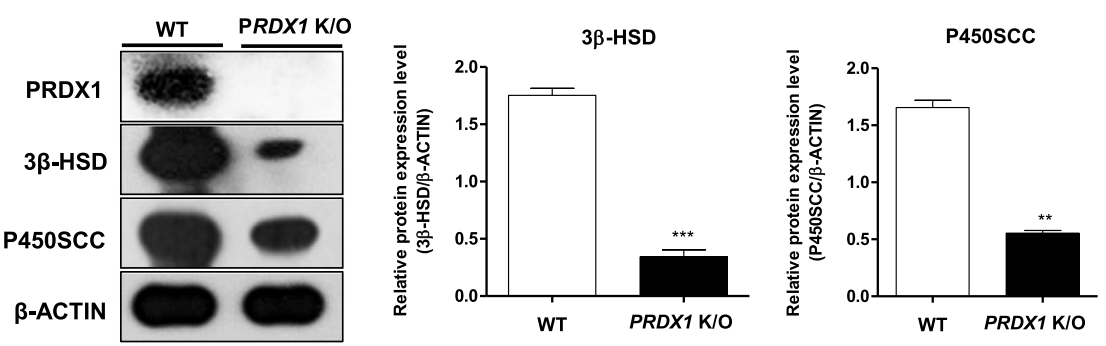

Fig. 4 The CL number, serum progesterone, 33-HSD, and P450ssc expression were decreased in Prdx1 K/O mice. a We performed genotyping of PRDX1 by PCR in the tail of Prdx1 K/O mice. $\mathbf{b} C L$ number in the ovary of Prd 1 K/O mice was observed by hematoxylin and eosin (H \& E) staining. c Serum progesterone levels were measured using a progesterone kit in Prdx 1 K/O mice. $\mathbf{d}$ The levels of the steroidogenic enzymes 3ß-HSD and P450SCC were determined in CL tissue by western blot analysis. The relative levels of these proteins were obtained after normalization with $\beta$-actin levels. The histogram values of densitometry analysis were obtained using the Image J software. The bars represent the mean of two independent experiments means \pm SEM (4-5 mice/group) ${ }^{*} P<0.05$, ${ }^{* *} P<0.01$, and ${ }^{* *} P<0.001$; two-tailed Student's t-test compared to WT mice

decreased activation of UPR signaling in response to ER stress during the functional luteal stage. We observed that the mRNA levels of the steroidogenic enzymes $3 \beta-\mathrm{HSD}$, StAR $(P<0.001$; compared to $\operatorname{Prdx1} \mathrm{K} / \mathrm{O}$ mice), and P450scc $(P<0.01$; compared to $\operatorname{Prdx} 1 \mathrm{~K} / \mathrm{O}$ mice) were recovered by NAC treatment (Fig. 6b). In contrast, the mRNA levels of CHOP $(P<0.001$ compared to Prdx $1 \mathrm{~K} / \mathrm{O}$ mice), GRP78/BIP, and p50ATF6 $(P<0.05$ compared to $\operatorname{Prdx1} \mathrm{K} / \mathrm{O}$ mice) in the CL tissue of NAC-treated $P r d x 1$ $\mathrm{K} / \mathrm{O}$ mice were significantly reduced (Fig. 6c). These results suggested that decrease in serum progesterone production and activation of UPR signaling in response to ER stress are restored by injecting NAC, a ROS scavenger, during the luteal stage of PRDX I KO mice.

\section{Discussion}

In this study, we demonstrated that the antioxidant activity of PRDX1 is required for maintaining progesterone production and the protein levels of enzymes involved in steroidogenesis via regulation of the UPR signaling pathway and ER stress response in the functional stage of mice CL. In addition, injection of the ROS scavenger NAC restored the reduction in progesterone production and activation of the UPR signaling pathway in response to ER stress in the CL tissue of $\operatorname{Prdx1} \mathrm{K} / \mathrm{O}$ mice. Therefore, PRDX1 may act as a regulator for progesterone production by reducing ER stress during the luteal functional stage.

It is well known that regulation of ROS production by various antioxidant enzymes is essential for the expression of enzymes related to steroidogenesis, and maintenance of progesterone production and hormone secretion by the CL [24]. During the secretory phase of the CL, $\mathrm{H}_{2} \mathrm{O}_{2}$ is produced from the CL tissue by monooxygenation, which is catalyzed by the P450scc steroidogenic enzyme $[14,25]$. The differential expression of antioxidant 


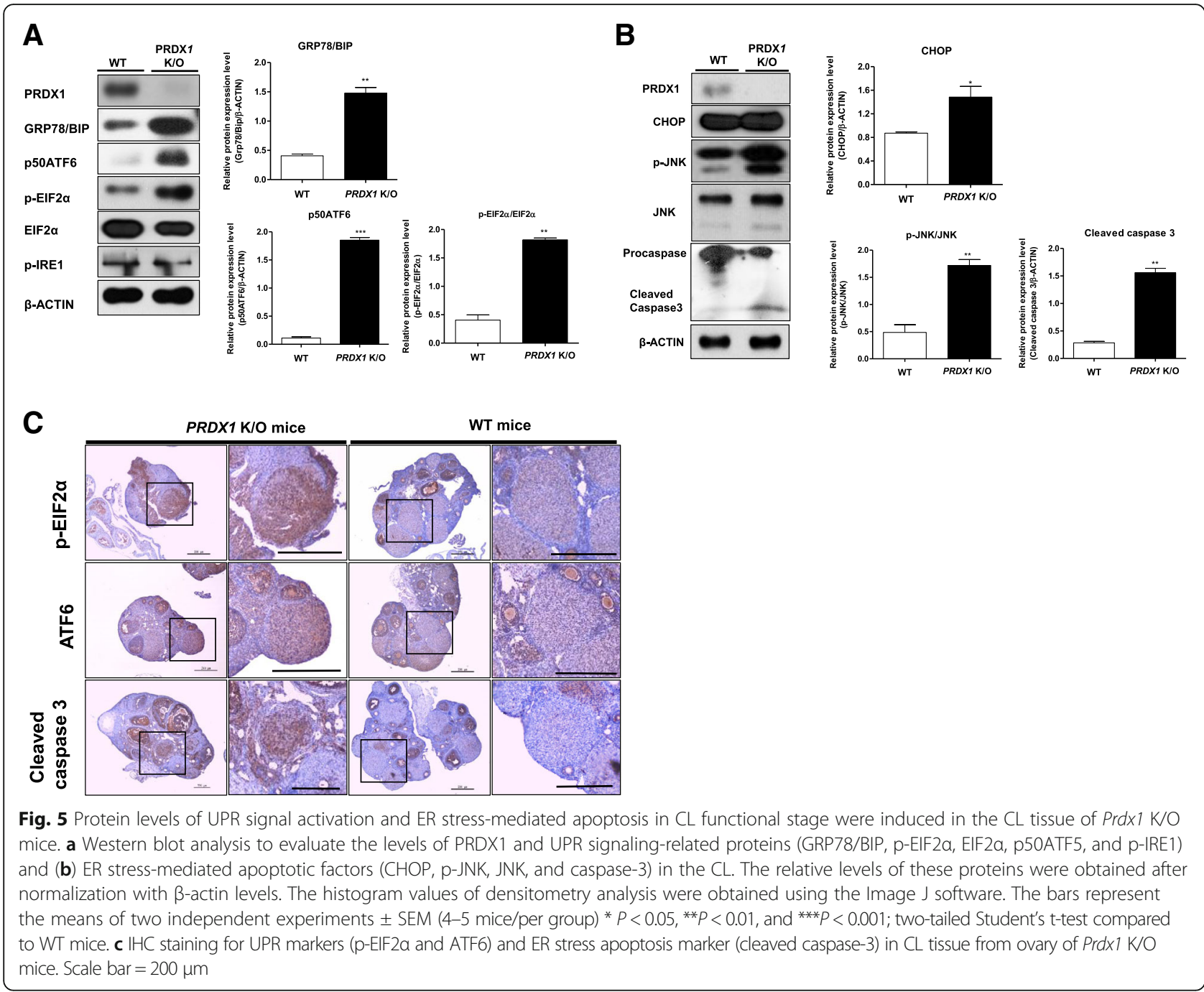

enzymes such as superoxide dismutase (SOD), catalase, and peroxiredoxins (PRDXs) suggest that oxidative stress affects ROS-related cellular mechanisms and the steroidogenic status of rat CL [26] and the bovine estrous cycle [27]. In this respect, although the roles of various antioxidant enzymes have been reported for female reproduction $[5,28]$, no direct information is available regarding the PRDX1 antioxidant system and its effect on progesterone production during the luteal phase.

Among these PRDXs, the protein levels of PRDX1 were continuously and highly expressed in the CL during the entire luteal phase (Fig. 3b). The levels of PRDX1, which protects against ER stress-mediated cell death by removing $\mathrm{H}_{2} \mathrm{O}_{2}$, was increased in the $\mathrm{CL}$ regression stage (Additional file 1: Figure S1). Protein level patterns of PRDX2, 3, 5, and 6 were irregularly expressed unrelated to $\mathrm{CL}$ formation, maintenance and regression progression in the $\mathrm{CL}$ during the entire luteal phase. The continuous high production of PRDX1 may stimulate ROS production from the $\mathrm{CL}$ tissue due to active metabolism and steroidogenesis during entire luteal phase (16-96 h PMSG/hCG injection). In addition, in $\operatorname{Prdx} 1 \mathrm{~K} / \mathrm{O}$ mice, the number of $\mathrm{CL}$ tissues in the ovary, serum progesterone levels, and expression of the main steroidogenesis enzymes were dramatically reduced compared to those in WT mice (Fig. 4). The luteal phase requires adequate secretions of progesterone by the $\mathrm{CL}$ [29]. In luteal phase deficiency or CL insufficiency is widely accepted to be female reproductive function defects, perhaps due to poor follicular development and an abnormality of ovarian function [30, 31]. Also, luteal phase defect is induced an ovulatory disorder of considerable clinical importance that is implicated in infertility and recurrent spontaneous abortion [32]. As a results of Fig. 4, depending on the decrease in the size of the ovaries in $\operatorname{Prdx} 1 \mathrm{~K} / \mathrm{O}$ mice, we speculated that the CL formation number and progesterone production level at $\mathrm{CL}$ functional stage $(48 \mathrm{~h})$ can reduced. Also, we analogized that it would appear that impaired follicular growth and ovulation can occur by decreased in $\mathrm{CL}$ formation 


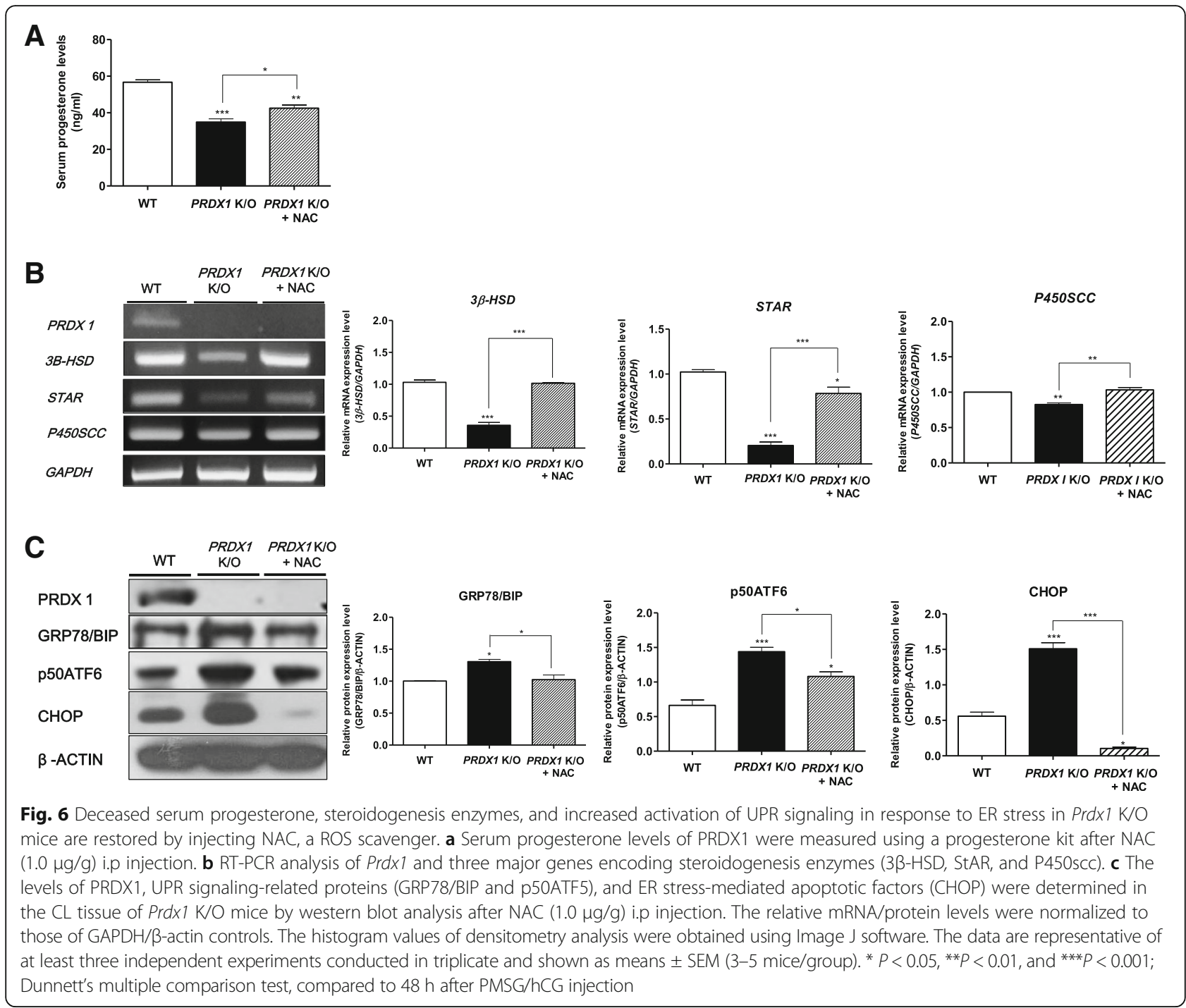

number in Prdx1 K/O mice. Therefore, our results demonstrate a link between the antioxidant enzyme PRDX1 and progesterone production in the CL of $\operatorname{Prdx} 1 \mathrm{~K} / \mathrm{O}$ mice, which may be critical in regulating ROS production by the anti-oxidative effects of PRDX1 during the functional stage of mouse CL.

The ER stress-associated oxidative environment may also be correlated with ER stress-associated ROS production [33]. ROS is generated during protein unfolding due to the depletion of antioxidant enzymes [33]. Thus, secreted proteins such as steroid hormones involved in ER-regulated protein folding may be more susceptible to higher levels of oxidative stress. ER stress and oxidative stress are closely linked events [33]. Reports show that prolonged ER stress leads to ROS production and oxidative stress via ER stress-mediated pro-apoptotic signaling $[34,35]$. We believe that the ER of luteal cells plays an important role as the site for steroidogenic enzyme synthesis and progesterone production during the $\mathrm{CL}$ functional stage. Previously, we observed that the progesterone production capacity of the CL tissue reduced after ER-stress inducer treatment [18].

We investigated whether N-acetyl-L-cysteine (NAC), which is widely used as a thiol-containing antioxidant [36], could protect progesterone production in WT mice after Tm administration. We also verified whether reduced progesterone production of $\operatorname{Prdx} 1 \mathrm{~K} / \mathrm{O}$ mice could be rescued by NAC administration. As shown in Fig. 2, serum progesterone level was recovered by NAC treatment in Tm pre-treated WT mice. In addition, the levels of $3 \beta-\mathrm{HSD}$ and P450scc steroidogenic enzymes were recovered and that of CHOP (ER stress-mediated apoptotic factor) was reduced by NAC or TUDCA treatment. Based on these results, we concluded that the regulation of ER stress-induced ROS is required for maintaining progesterone production during the mouse 
luteal phase. In $\operatorname{Prdx1} \mathrm{K} / \mathrm{O}$ mice, NAC administration also recovered progesterone production and the levels of steroidogenic enzymes and $\mathrm{CHOP}$ (Fig. 6). In addition, the levels of serum progesterone and steroidogenic enzymes in $\operatorname{Prdx1}$ heterozygous mice showed the same pattern as in WT mice (Additional file 2: Figure S2). PRDX1 expression is upregulated following exposure to oxidative stress [10]. In agreement with this observation, we observed that Tm treatment increased PRDX1 expression, which was significantly recovered by NAC or TUDCA (Fig. 3c and d). We believe that the antioxidant enzyme PRDX1 is upregulated by the ER stress-associated oxidative environment of the mouse luteal phase. In the present study, NAC administration rescued luteal function by restoring progesterone production and reducing ER stress in the CL of $\operatorname{Prdx} 1 \mathrm{~K} / \mathrm{O}$ mice (Fig. 6). Therefore, these results demonstrate that PRDX1 is a regulator of ER stress-induced ROS production that is required for maintaining progesterone production during the functional stage in mouse CL.

Several studies have demonstrated a crosstalk between the production of ROS and UPR signal-induced ER stress response $[15,37,38]$. Previously, we showed that UPR is involved in steroidogenic enzyme expression in hCG-stimulated Leydig cells [22] and regulation of CL function in mice luteal phase [18]. The UPR signaling pathways were activated in response to ER stress, which plays important roles in the regulation of CL function, and $E R$ stress-mediated apoptosis occurs via three activated UPR pathways (PERK, ATF6, and IRE1) in the CL regression stage. To determine whether the loss in progesterone production depends on PRDX1, we attempted to identify a functional link between PRDX1 and UPR signaling (GRP78/BIP, p-eIF2 $\alpha$, p50ATF6, and p-IRE1) and ERstress mediated apoptotic factors ( $\mathrm{p}-\mathrm{JNK}, \mathrm{CHOP}$, and cleaved caspase-3) in the functional stage using WT and $\operatorname{Prdx1} \mathrm{K} / \mathrm{O}$ mice. As shown in Fig. 5a and b, GRP78/BIP, p-eIF2 $\alpha$, p50ATF6, p-JNK, CHOP, and cleaved caspase-3 were upregulated in the $\mathrm{CL}$ functional stage in the $\operatorname{Prdx} 1$ K/O mice. In addition, p50ATF6, p-eIF $2 \alpha$ and cleaved caspase-3 were detected in the CL tissue of $\operatorname{Prdx} 1 \mathrm{~K} / \mathrm{O}$ mice by immunohistochemical staining (Fig. 5c). Interestingly, although the exact molecular mechanism has not been fully elucidated, phosphorylation of the UPR marker IRE1 was not affected in the $\operatorname{Prdx} 1 \mathrm{~K} / \mathrm{O}$ mice. Activation of GRP78/BIP and p50ATF6 were also significantly reduced by NAC administration in $\operatorname{Prdx} 1 \mathrm{~K} / \mathrm{O}$ mice (Fig. 6c.). Therefore, the present study demonstrates a link between the antioxidant enzyme PRDX1 and progesterone production via regulation of UPR signaling and ER stress response. Consequently, PRDX1 deficiency activated the UPR signaling pathways and ER stress-mediated apoptosis in the CL functional stage. These novel observations suggest that PRDX1 may be component of a regulatory network for luteal functions that specifically reduce ROS.

\section{Conclusion}

In conclusion, our findings demonstrate that PRDX1 is an antioxidant enzyme, which is essential for preserving progesterone production against ER stress-associated oxidative stress in the CL functional stage (Fig. 7). PRDX1 deficiency decreased progesterone production via ER-stress induced ROS generation in CL tissue. Therefore, PRDX1 is required for the maintenance of luteal function via regulation of UPR signaling pathways in response to ER stress in mice. These findings highlight the basic mechanisms underlying PRDX1 antioxidant activity, which will enhance our understanding of the relationship between antioxidant enzymes and progesterone production in CL functional stage.
[ Wild type mice ]

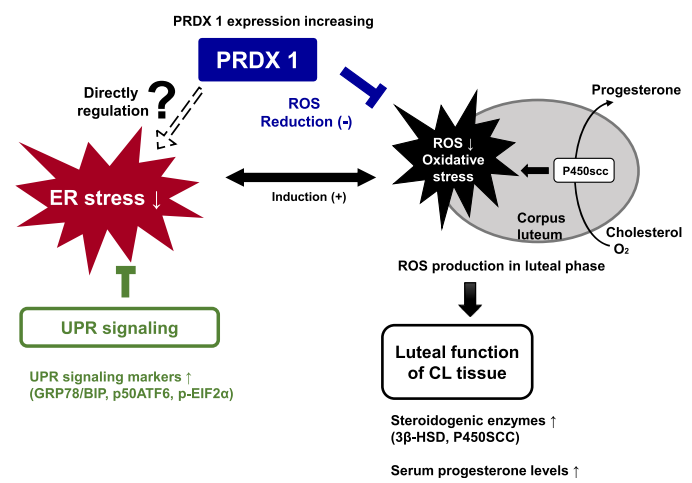

[ PRDX1 K/O mice ]

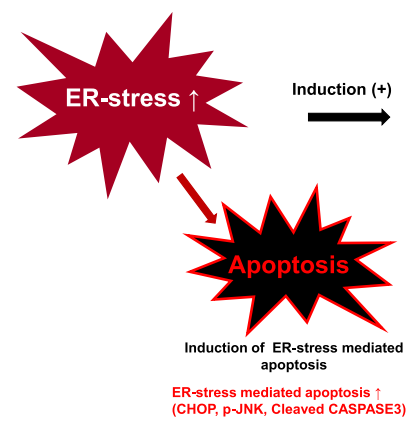

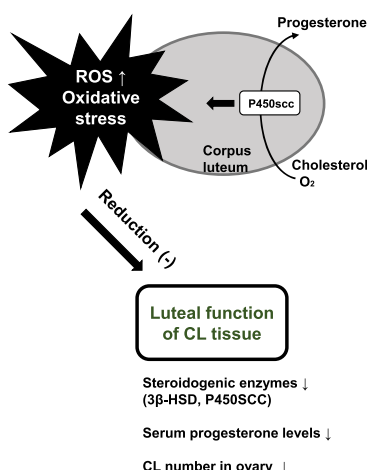

CL number in ovary $\downarrow$

Fig. 7 Roles of PRDX1 on progesterone production, and UPR signaling activation in CL tissue of mice. Graphical summary. Right panel; ROS reduction by PRDX1 during the luteal functional stage (48 $\mathrm{h}$ after PMSG/hCG injection) in WT mice decreased activated UPR signaling in response ER stress and increased steroidogenesis enzymes expression in the $\mathrm{CL}$ to promote progesterone production. Left panel; Increasing ROS by PRDX1 deficiency during the luteal functional stage of Prdx1 K/O mice increased activated UPR signaling in response ER stress mediated apoptosis and decreased progesterone production related steroidogenesis enzymes expression in $\mathrm{CL}$ tissue and serum progesterone levels 


\section{Additional files}

Additional file 1: Figure S1. Changes in PRDX family (2-6) protein levels in luteal phase of WT mice. Protein levels of PRDX 2-6 were confirmed in $\mathrm{CL}$ tissue by western blot analysis (A). The relative levels of PRDX proteins were obtained after normalization to $\beta$-actin levels. The histogram values of densitometry analysis were obtained using the Image J software. The bar graph data represent the least-squares means \pm SEM of three independent experiments. ${ }^{*} P<0.05$, ${ }^{*} P<0.01$, and ${ }^{* *} P<0.001$; Dunnett's multiple comparison test compared to $16 \mathrm{~h}$ after PMSG/hCG injection. (DOCX $281 \mathrm{~kb}$ )

Additional file 2: Figure S2. Effects of PRDX1 on progesterone production in $\mathrm{CL}$ tissue using $\operatorname{Prd} \times 1$ heterozygous and $\mathrm{K} / \mathrm{O}$ mice. We observed ovary morphology in wild type, Prdx1 K/O and heterozygous mice (A). Serum progesterone levels were measured using a progesterone kit in $\operatorname{Prd} 1 \times 1 \mathrm{~K} / \mathrm{O}$ and heterozygous mice (B). The levels of steroidogenic enzymes 3 3 -HSD and P450SSC were determined in the CL tissue using western blot analysis. The relative levels of the steroidogenic enzymes were normalized to $\beta$-actin levels (C). Western blotting analysis of the ER stress marker $\mathrm{CHOP}$ in $\mathrm{CL}$ tissue of Prdx 1 heterozygous and $\mathrm{K} / \mathrm{O}$ mice. The relative levels of $\mathrm{CHOP}$ were normalized to $\beta$-tubulin levels (control). (D) The histogram values of densitometry analysis were obtained using the Image J software. The bar graphs represent the least-squares means \pm SEM of three independent experiments. ${ }^{*} P<0.05$, ${ }^{*} P<0.01$, and ${ }^{* *} P<0.001$; Dunnett's multiple comparison test compared to $48 \mathrm{~h}$ after PMSG/hCG injection. (DOCX $331 \mathrm{~kb}$ )

\section{Abbreviations}

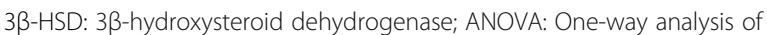
variance; ATF6: Activating transcription factor-6; BSA: Bovine serum albumin; CAT: Catalase; CHOP: C/EBP homologous protein; CL: Corpus luteum; DAB: 3'diaminobenzidine; ECL: Enhanced chemiluminescence; ER: Endoplasmic reticulum; GPX: Glutathione peroxidase; $\mathrm{H}_{2} \mathrm{O}_{2}$ : Hydrogen peroxide; hCG: Human chorionic gonadotropin/mouse; HRP: Horse radish peroxidase; IHC: immunohistochemistry; IRE1 or ERN1: Inositol-requiring enzyme 1; JNK: cJUN NH2-terminal kinase; K/O: Knockout; NAC: N-acetylcysteine; NC: Nitrocellulose; P450scc: P450 cholesterol side-chain cleavage enzyme; PERK: Protein kinase RNA (PKR)-like ER kinase; PMSG: Pregnant mare's serum gonadotropin; PRDX1: Peroxiredoxin 1; PRDXs: Peroxiredoxins; ROS: Reactive oxygen species; SDS-PAGE: Sodium dodecyl sulfate-polyacrylamide gel electrophoresis; SEM: Standard error of the mean; SOD: Superoxide dismutase; StAR: Steroidogenic acute regulatory; TBS: Tris-buffered saline; Tm: Tunicamycin; UPR: Unfolded protein response; WT: Wild type

\section{Funding}

This research was supported by grants from the National Research Foundation of Korea Government (NRF-2017R1A5A2015391, NRF- 2017R1A2B4008176 and NRF-2015R1A4A1042271), and by grants from the Korea Research Institute of Bioscience \& Biotechnology (KRIBB) Research Initiative Program (KGM4611821), Republic of Korea.

\section{Availability of data and materials}

All data generated or analyzed during this study are included in this published article.

\section{Author's contributions}

HJP conceived the study, performed the in vitro culture of pig oocytes, western blotting analysis, and RT-PCR, and collected and interpreted the data. DGL, JBS, SRL, SL: data collection, analysis, and interpretation. HSL, OSK, JWP, BSK: study design and financial support. DSL conceived and designed the study, analyzed and interpreted data, wrote the manuscript, arranged for financial support, and finally approved the manuscript. All authors read and approved the final manuscript.

\section{Ethics approval}

All animal care and experimental protocols used in this study were approved by the Institutional Animal Care and Use Committee of KRIBB (permit number: KRIBB-AEC-17092).

\section{Consent for publication}

Not applicable

\section{Competing interests}

The authors declare that they have no competing interests.

\section{Publisher's Note}

Springer Nature remains neutral with regard to jurisdictional claims in published maps and institutional affiliations.

\section{Author details}

${ }^{1}$ College of Engineering, Daegu University, Biotechnology, Gyeongsan, South Korea. ${ }^{2}$ School of Life Sciences, BK21 Plus KNU Creative BioResearch Group, Kyungpook National University, Daegu, South Korea. ${ }^{3}$ Korea Research Institute of Bioscience and Biotechnology (KRIBB), National Primate Research Center (NPRC), Daejeon, South Korea. ${ }^{4}$ College of Natural Sciences, Kyungpook National University, Daegu 702-701, Republic of Korea.

\section{Received: 26 April 2018 Accepted: 7 August 2018}

Published online: 15 August 2018

\section{References}

1. Tanghe S, Van Soom A, Nauwynck H, Coryn M, de Kruif A. Minireview: functions of the cumulus oophorus during oocyte maturation, ovulation, and fertilization. Mol Reprod Dev. 2002;61:414-24.

2. Al-Gubory KH, Garrel C, Faure P, Sugino N. Roles of antioxidant enzymes in corpus luteum rescue from reactive oxygen species-induced oxidative stress. Reprod BioMed Online. 2012;25:551-60.

3. Al-Gubory KH, Fowler PA, Garrel C. The roles of cellular reactive oxygen species, oxidative stress and antioxidants in pregnancy outcomes. Int J Biochem Cell Biol. 2010;42:1634-50.

4. Behrman HR, Kodaman PH, Preston SL, Gao S. Oxidative stress and the ovary. J Soc Gynecol Investig. 2001;8:S40-2.

5. Agarwal A, Aponte-Mellado A, Premkumar BJ, Shaman A, Gupta S. The effects of oxidative stress on female reproduction: a review. Reprod Biol Endocrinol. 2012;10:49

6. Pham-Huy LA, He H, Pham-Huy C. Free radicals, antioxidants in disease and health. Int J Biomed Sci. 2008:4:89-96.

7. Agarwal A, Gupta S, Sharma RK. Role of oxidative stress in female reproduction Reprod Biol Endocrinol. 2005;3:28

8. Nicolussi A, D'Inzeo S, Capalbo C, Giannini G, Coppa A. The role of peroxiredoxins in cancer. Mol Clin Oncol. 2017;6:139-53.

9. Immenschuh S, Baumgart-Vogt E. Peroxiredoxins, oxidative stress, and cell proliferation. Antioxid Redox Signal. 2005;7:768-77.

10. Lee Yl, Kang WD, Kim MY, Cho MK, Chun SY. Expression of peroxiredoxin regulated by gonadotropins in the rat ovary. Clin Exp Reprod Med. 2011;38: $18-23$.

11. Niswender GD, Juengel JL, Silva PJ, Rollyson MK, Mclntush EW. Mechanisms controlling the function and life span of the corpus luteum. Physiol Rev. 2000;80:1-29.

12. Black VH, Sanjay A, van Leyen K, Lauring B, Kreibich G. Cholesterol and steroid synthesizing smooth endoplasmic reticulum of adrenocortical cells contains high levels of proteins associated with the translocation channel. Endocrinology. 2005;146:4234-49.

13. Christenson LK, Devoto L. Cholesterol transport and steroidogenesis by the corpus luteum. Reprod Biol Endocrinol. 2003;1:90.

14. Fujii J, luchi Y, Okada F. Fundamental roles of reactive oxygen species and protective mechanisms in the female reproductive system. Reprod Biol Endocrinol. 2005;3:43.

15. Zeeshan HM, Lee GH, Kim HR, Chae HJ. Endoplasmic reticulum stress and associated ROS. Int J Mol Sci. 2016;17:327.

16. Schroder M, Kaufman RJ. ER stress and the unfolded protein response. Mutat Res. 2005;569:29-63.

17. Oyadomari S, Mori M. Roles of CHOP/GADD153 in endoplasmic reticulum stress. Cell Death Differ. 2004;11:381-9.

18. Park HJ, Park SJ, Koo DB, Lee SR, Kong IK, Ryoo JW, Park YI, Chang KT, Lee DS. Progesterone production is affected by unfolded protein response (UPR) signaling during the luteal phase in mice. Life Sci. 2014;113:60-7.

19. Park HJ, Park SJ, Koo DB, Kong IK, Kim MK, Kim JM, Choi MS, Park YH, Kim $\mathrm{SU}$, Chang KT, et al. Unfolding protein response signaling is involved in development, maintenance, and regression of the corpus luteum during the bovine estrous cycle. Biochem Biophys Res Commun. 2013;441:344-50. 
20. Tavender TJ, Bulleid NJ. Peroxiredoxin IV protects cells from oxidative stress by removing H2O2 produced during disulphide formation. J Cell Sci. 2010; 123:2672-9.

21. Byers SL, Wiles MV, Dunn SL, Taft RA. Mouse estrous cycle identification tool and images. PLoS One. 2012;7:e35538.

22. Park SJ, Kim TS, Park CK, Lee SH, Kim JM, Lee KS, Lee IK, Park JW, Lawson MA, Lee DS. hCG-induced endoplasmic reticulum stress triggers apoptosis and reduces steroidogenic enzyme expression through activating transcription factor 6 in Leydig cells of the testis. J Mol Endocrinol. 2013;50:151-66.

23. Burrill JS, Long EK, Reilly B, Deng Y, Armitage IM, Scherer PE, Bernlohr DA. Inflammation and ER stress regulate branched-chain amino acid uptake and metabolism in adipocytes. Mol Endocrinol. 2015;29:411-20.

24. Foyouzi N, Cai Z, Sugimoto Y, Stocco C. Changes in the expression of steroidogenic and antioxidant genes in the mouse corpus luteum during luteolysis. Biol Reprod. 2005;72:1134-41.

25. Riley JC, Behrman HR. In vivo generation of hydrogen peroxide in the rat corpus luteum during luteolysis. Endocrinology. 1991;128:1749-53.

26. Lee SY, Lee JY, Oh SJ, Kim HC, Kim SK. Expression of hepatic and ovarian antioxidant enzymes during estrous cycle in rats. Toxicol Lett. 2012;212:329-36

27. Rapoport R, Sklan D, Wolfenson D, Shaham-Albalancy A, Hanukoglu I. Antioxidant capacity is correlated with steroidogenic status of the corpus luteum during the bovine estrous cycle. Biochim Biophys Acta. 1998;1380:133-40.

28. Banmeyer I, Marchand C, Verhaeghe C, Vucic B, Rees JF, Knoops B. Overexpression of human peroxiredoxin 5 in subcellular compartments of Chinese hamster ovary cells: effects on cytotoxicity and DNA damage caused by peroxides. Free Radic Biol Med. 2004:36:65-77.

29. Mesen TB, Young SL. Progesterone and the luteal phase: a requisite to reproduction. Obstet Gynecol Clin N Am. 2015;42:135-51.

30. Ayabe T, Tsutsumi O, Momoeda M, Yano T, Mitsuhashi N, Taketani Y. Impaired follicular growth and abnormal luteinizing hormone surge in luteal phase defect. Fertil Steril. 1994;61:652-6.

31. Hinney B, Henze C, Kuhn W, Wuttke W. The corpus luteum insufficiency: a multifactorial disease. J Clin Endocrinol Metab. 1996:81:565-70.

32. Ginsburg KA. Luteal phase defect. Etiology, diagnosis, and management Endocrinol Metab Clin N Am. 1992;21:85-104.

33. Bhandary B, Marahatta A, Kim HR, Chae HJ. An involvement of oxidative stress in endoplasmic reticulum stress and its associated diseases. Int J Mol Sci. 2012;14:434-56.

34. Malhotra JD, Kaufman RJ. Endoplasmic reticulum stress and oxidative stress: a vicious cycle or a double-edged sword? Antioxid Redox Signal. 2007;9: 2277-93.

35. Malhotra JD, Miao H, Zhang K, Wolfson A, Pennathur S, Pipe SW, Kaufman RJ. Antioxidants reduce endoplasmic reticulum stress and improve protein secretion. Proc Natl Acad Sci U S A. 2008:105:18525-30.

36. Halasi M, Wang M, Chavan TS, Gaponenko V, Hay N, Gartel AL. ROS inhibitor $\mathrm{N}$-acetyl-L-cysteine antagonizes the activity of proteasome inhibitors. Biochem J. 2013;454:201-8.

37. Cao SS, Kaufman RJ. Endoplasmic reticulum stress and oxidative stress in cell fate decision and human disease. Antioxid Redox Signal. 2014;21:396-413.

38. Eletto D, Chevet E, Argon Y, Appenzeller-Herzog C. Redox controls UPR to control redox. J Cell Sci. 2014;127:3649-58.

Ready to submit your research? Choose BMC and benefit from:

- fast, convenient online submission

- thorough peer review by experienced researchers in your field

- rapid publication on acceptance

- support for research data, including large and complex data types

- gold Open Access which fosters wider collaboration and increased citations

- maximum visibility for your research: over $100 \mathrm{M}$ website views per year

At BMC, research is always in progress.

Learn more biomedcentral.com/submissions 